\title{
Bone Morphogenetic Protein Functions as a Context-Dependent Angiogenic Cue in Vertebrates
}

\author{
David M. Wiley ${ }^{1,2}$ and Suk-Won Jin ${ }^{1,2,3, \dagger}$ \\ ${ }^{1}$ McAllister Heart Institute, University of North Carolina at Chapel Hill, Chapel Hill, NC, 27599 \\ ${ }^{2}$ Dept. of Biology, University of North Carolina at Chapel Hill, Chapel Hill, NC, 27599 \\ ${ }^{3}$ Dept. of Cell and Molecular Physiology, University of North Carolina at Chapel Hill, Chapel Hill, \\ NC, 27599
}

\begin{abstract}
Bone Morphogenetic Protein (BMP) signaling has been implicated in diverse biological processes. Although how BMP signaling regulates behaviors of endothelial cells during angiogenesis are not fully understood, increasing evidence indicate functions of BMP signaling components are essential in developmental and pathological angiogenesis. Here we review recent advances in delineating the functions of BMP signaling during angiogenesis. In addition, we discuss downstream pathways that transduce BMP signaling in endothelial cells, and factors that modulate BMP signaling response in endothelial cells. Finally, we provide recent insight on how BMP signaling functions as a context dependent angiogenic cue.
\end{abstract}

\section{Introduction}

Bone Morphogenetic Protein (BMP) signaling is involved in diverse morphogenetic processes during development including bone and cartilage formation, early embryonic patterning along the dorsal-ventral axis, specification of endodermal organs [1], as well as pathological situations. However, its function during angiogenesis, the process by which new blood vessels form from pre-existing vessels, remains largely unknown. Although the Vascular Endothelial Growth Factor (VEGF) signaling pathway is well established as a major regulator of angiogenesis [2,3], complex vascular networks require input from multiple signaling pathways to pattern properly. Therefore, understanding the role of additional regulators of angiogenesis, such as the Bone Morphogenetic Protein (BMP) pathway, will help elucidate the complex mechanisms involved during angiogenesis.

\section{Overview of BMP signaling cascade}

BMP growth factors are members of the TGF- $\beta$ super-family [4]. BMP ligands dimerize and bind to a tetraheteromeric receptor complex composed of two type I and two type II BMP receptors. Additionally, Type III receptors, such as Endoglin, can interact and modulate ligand affinity for type I and type II receptors. Once the signaling complex forms, the kinase

(C) 2011 Elsevier Ltd. All rights reserved.

Correspondence: suk-won.jin@yale.edu.

†Current address: Section of Cardiovascular Medicine, Dept. of Medicine, Yale Medical School, New Haven, CT, 06511

Publisher's Disclaimer: This is a PDF file of an unedited manuscript that has been accepted for publication. As a service to our customers we are providing this early version of the manuscript. The manuscript will undergo copyediting, typesetting, and review of the resulting proof before it is published in its final citable form. Please note that during the production process errors may be discovered which could affect the content, and all legal disclaimers that apply to the journal pertain. 
domain of the type I BMP receptor phosphorylates and activates SMAD1, SMAD5, and SMAD8 (R-SMADs). Activated R-SMADs bind SMAD4 (co-SMAD) and translocate to the nucleus to initiate transcription of downstream target genes (Fig. 1). In addition to activating the SMAD signaling cascade, BMP signaling can also act through SMAD-independent mechanisms. For instance, BMP signaling can activate MAPK such as Erk and p38 [5].

\section{Human pathological conditions caused by BMP signaling dysregulation}

In humans, mutations of various BMP signaling components have been linked to various pathological conditions affecting the vascular system. Mutations in the $E N G$ gene and ACVRL1, (ENG encodes for the type III receptor, Endoglin; and ACVRL1 encodes for a type I receptor, ALK1) cause Hemorrhagic Hereditary Telangiectasia (HHT) 1 and HHT2 respectively $[6,7]$. HHT is an autosomal dominant vascular dysplasia characterized by recurrent nose bleeds, mucocutaneous telangiectases (small dilated blood vessels), and arteriovenous malformations (AVMs) [8]. Similarly, genetic manipulation of Endoglin and ALK1 in mice replicates many of the characteristics of HHT [9-13].

In addition, several components of BMP signaling pathway have been linked to pulmonary arterial hypertension (PAH) in humans. PAH is a progressive disorder thought to arise from abnormal endothelial cell growth and maintenance. PAH causes an increase in arterial pressure, occlusions in pulmonary arteries, and can even lead to heart failure. The primary gene associated with PAH is BMPR2. However, mutations in ALK1,Endoglin, or SMAD8 have also been implicated in PAH [14-16]. Genetic manipulations in murine models also recapitulate the pathological symptoms found in humans. Global deletion of one copy of the BMPRII gene exhibited increased pulmonary vascular resistance and thickened arteries in mice [17]. Interestingly, global reduction of $B M P R 2$ by shRNA transgene caused a mucosal hemorrhages and incomplete mural cell coverage, phenotypes which are the common characteristics of HHT [18]. This suggests that BMP signaling is critical in the pathophysiology of PAH.

\section{Ligand-receptor complexes}

The BMP signaling pathway contains multiple BMP ligands which are subdivided in to groups based on sequence and function [19]. BMP2 and BMP4 form the BMP2/4 subgroup; BMP5, BMP6, BMP7, and BMP8 form the BMP7 subgroup; Growth Differentiation Factor (GDF) 5, GDF6, and GDF7 form the GDF5 subgroup, and BMP9 and BMP10 form a fourth subgroup.

BMP ligands, once secreted, readily form a homodimer via a disulfide bond and are stabilized. Homodimers of various BMP ligands are capable of signaling. However, recent studies suggested that heterodimeric BMP ligands can induce more robust downstream activation than homodimeric BMP ligands. For instance, during zebrafish development, $\mathrm{Bmp} 2 \mathrm{~b} / 7$ ligand is a more potent regulator for dorsoventral patterning than Bmp2b or Bmp7 homodimer [20].

There are at least four type I receptors and three type II receptors that BMP ligands can interact with; Alk1, Alk2, Alk3, and Alk6 are the type I receptors, and BMP receptor type II (BMPRII), Activin Receptor type IIA and B (ACTRIIA, and ACTRIIB) are the type II receptors. Additionally, Type III receptors, such as Endoglin, can interact and modulate ligand affinity for its type I and type II receptors.

The sequence in which BMP ligands bind type I and type II receptors depends on the relative binding affinity. BMP2 and BMP4 have a high affinity for Alk3 and Alk6 type I receptors which recruit BMPRII/ActRII and ActRIIB type II receptors [21, 22]. BMP6 and 
BMP7 interact with ActRII/ActRIIB and recruit Alk2, Alk3 and Alk6 [22-24]. GDF5 and GDF6 interact with Act RII, Act RIIB and BMP RII and Alk6 [25, 26]. BMP9 and BMP10 interact with ALK1 and BMPRII/ActRII [27, 28]. The composition of the Bmp signaling complexes likely underlies the diverse effects observed through BMP signaling (Fig. 1).

\section{Ligands}

In the mammalian system, there are at least 20 BMP ligands present. During development, diverse BMP ligands are widely expressed and many of them show overlapping yet distinct pro- and/or anti-angiogenic properties.

BMP2

Multiple in vivo studies have analyzed the affects of BMP2 and BMP4 on angiogenesis. BMP-2 induces blood vessel formation in tumors formed from A549 cells and enhanced angiogenesis in Matrigel plugs containing these cells [29]. Other study independently showed that BMP2 overexpression in MCF-7 breast cells also induced vessel formation in tumors, demonstrated that BMP2-induced vessel formation in the mouse sponge assay [30].

In vitro, BMP2 stimulates proliferation of human aortic endothelial cells (HAEC) [29] and pulmonary aortic endothelial cells (PAEC) [31]. BMP2 increases the migration of microvascular endothelial cells (HMEC) [32], and increases tube formation in human aortic endothelial cells (HAEC), human umbilical vein endothelial cells (HUVEC) [29] and HMECs [32].

\section{BMP4}

Over-expression of BMP4 in the paraxial or lateral plate mesoderm [33] and grafts of BMP-4 beads in the paraxial mesoderm of quail embryos induced ectopic vessel formation [34]. In addition, BMP4 stimulus induced angiogenesis in the chicken chorioallantoic membrane (CAM) assay [35].

BMP4 induced the proliferation of mouse embryonic stem cell-derived endothelial cells (MESEC) and HMECs [36]. BMP4 increased cell migration in quail embryonic endothelial cells (QEECs), HUVECs, [33], HMECs [32], and MESECs [36]. Bmp4 increased tube formation of HMEC [36] and mouse aortic endothelial cells (MAEC) [35].

\section{BMP6, 7}

BMP6 induced microvessel outgrowth in aortic rings [37], proliferation in mouse embryonic endothelial cells (MECs) [37], migration in bovine aortic endothelial cells (BAEC) [38] and MECs [37], and tube formation in BAECs [38]. Similarly, BMP7 induced angiogenesis in the CAM assay [39].

\section{GDF5}

GDF5 increased vessel formation in the CAM assay and in the rabbit cornea assay and increased migration of BAECs [40].

\section{BMP9,10}

BMP9 inhibited vessel growth in the mouse sponge assay [41] and blocked new vessel growth in a metatarsal angiogenesis assay [42]. Bmp9 inhibited proliferation and migration of BAECs [42]. BMP9 and the closely related BMP10 inhibit the proliferation and migration of HMECs [28]. 


\section{Receptors}

Similar to BMP ligands, both BMP Type I and Type II receptors are widely expressed in vertebrate embryos during development, and many of them modulate angiogenesis.

\section{Type I receptors}

The majority of type I receptors of BMP signaling appear to have pro-angiogenic functions. Constitutively active forms of ALK2, ALK3 and ALK6 promoted endothelial cell migration and tube formation in BAECs [38].

Interestingly, the function of ALK1, another type I receptor, appears to be more complicated. Lesions in the zebrafish alk1 gene caused an increase in endothelial cell number and dilated cranial vessels, indicating that ALK1 in this setting may inhibit certain aspects of angiogenesis [43]. Similarly, expression of constitutively active ALK1 (ALK1CA) inhibited endothelial sprouting from embryoid bodies [44], and inhibited proliferation and migration of HMECs and HUVECs [45]. However, ALK1CA overexpression increased the cell migration of MEECs [46]. Given that ALK1 can associate with multiple TGF- $\beta$ /BMP ligands and receptors, it is likely that different associations may account for complex ALK1 deficient phenotypes and inconsistencies between these studies.

\section{Type II receptors}

In humans and mice, lack of BMPR2 caused aberrant growth of endothelial cells in pulmonary vessels and increased arterial pressure, symptoms frequently found in PAH. In zebrafish, two BMPR2 orthologs, Bmpr2a and Bmpr2b, have been identified. The morpholino-mediated knockdown of either of these genes inhibited angiogenesis [47].

\section{Additional receptor regulation}

BMP receptor complexes can exist as preformed complexes (PFC), which become activated upon ligand binding. Alternatively, BMP receptor complexes can be induced by ligand binding to a single receptor, which recruits other subunits of BMP receptor complexes, forming a BMP induced signaling complex (BISC). While PFC is internalized by Clathrin mediated endocytosis and preferentially activate SMAD pathway, BISC is internalized by caveosome and activates the Mitogen Activated Protein Kinase (MAPK) pathway [48-50].

Bmp receptors also interact with a number of co-receptors ranging from GPI-anchored proteins to receptor tyrosine kinase (RTK) [51-55]. Co-receptors such as Dragon (a member of repulsive guidance molecules) and c-Kit (a well characterized RTK) can enhance Bmp signaling by physically binding to Bmp ligands and receptors simultaneously. Others receptors that signal through Bmp receptors include the RTKs TrkC and Ror2, and decoy receptor Bambi. Bambi can attenuate Bmp signaling by competing with Bmp type I receptor [56].

Unlike other TGF- $\beta$ receptors, BMPRII has a long carboxy terminal tail, which is regulated independent of type I receptors. The BMPRII cytoplasmic tail has been implicated in regulating many processes by directly interacting with many factors including LIMK1, (a kinase which regulates of actin dynamics) [57], Tctex-1 (a light chain of dynein) [58], c-Src (a tyrosine kinase) [59], and Jiraiya (a membrane protein) [60]. Therefore, the carboy terminal of BMPRII may play a critical role in regulating angiogenesis independent of the heteromeric receptor complex. 


\section{Antagonists}

Several secreted proteins that function as antagonists of BMP signaling have been identified. Like BMP ligands, these proteins contain multiple Cysteine residues used to form disulfide bonds with BMP ligands, which in turn interfere with the ligand-receptor recognition [61]. Based on the number of the Cysteine residues and the size of the resulting Cystine-knot structure, BMP antagonists can be divided into three main subgroups. Members of differential screening-selected gene aberrative in neuroblastoma (DAN) family of BMP antagonists include Cerberus [62, 63], Gremlin [64], and Sclerostin [65], and a have eightmembered ring Cystine-knot. Proteins related to Twisted gastrulation [66] have a ninemembered ring Cystine-knot, and Chordin [67]and Noggin [68] have a ten-membered ring Cystine-knot [61]. Members within each subgroup appear to be more phylogenetically related, suggesting that each subgroup of BMP antagonists is evolutionarily distinct [69]. While most of BMP antagonists function as homodimers rings [61], recently identified BMP antagonists, Sclerostin and related Uterine Sensitization Associated Gene-1 (USAG-1), function as monomers [70, 71].

Bmp antagonists appear to play a pivotal function during angiogenesis. Recent studies have demonstrated that the area near the midline of embryos remains avascular since the nearby notochord inhibits the migration of endothelial cells by secreting two main BMP antagonists, Noggin and Chordin [72, 73]. Furthermore, Noggin and Chordin also appear to be critical for regulating the fusion of the developing dorsal aorta in avians [74].

One BMP antagonist, Crossveinless-2 (Cvl2), also known as Bmper [75, 76], is selectively express in an endothelial specific manner during development [75]. Interestingly, unlike the majority of BMP antagonists, Cvl2 can function as a BMP agonist and/or antagonist in a context dependent manner [77-79]. A lower concentration of Cvl2 can facilitate phosphorylation of SMAD-1/5/8, while a higher concentration attenuates the efficacy of BMP signaling[80]. Accordingly, in developing vessels, lower concentration of Cvl2 activates sprouting and angiogenesis, while higher concentration inhibits this process [78]. By investigating the effects of Cvl2 on BMP4 signaling, Kelley and colleagues have shown that Clv2 can directly bind to BMP4 and can interfere with its interaction with BMP Type II receptor. This leads to decreased Clathrin-mediated internalization of BMP ligand-receptor complexes [78]

\section{Downstream signaling cascade and cross-talk with other pathways}

Binding to BMP ligand to heteromeric BMP receptor complexes trigger activation of diverse downstream signaling cascades, resulting in transcriptional activation of target genes. For instance, BMP6 transcriptionally activated ID1 through the SMAD signaling cascade. Overexpression of ID1 induced EC migration and tube formation in BAECs, mimicking the affects of BMP6 [38]. Microarray analysis found that treating MECs with BMP6 caused a transcriptional increase in Cox2 (a gene that catalyzes the conversion of Arachidonic acid to Prostaglandins) and MyoX (an atypical myosin critical for filopodial formation). Cox 2 mediated BMP6-induced proliferation, migration, and network assembly of MECs as well as microvessel outgrowth in aortic rings [37]. In addition, MyoX induction through BMP6 is necessary for filopodial formation, cell alignment, directed migration, and tube formation in MECs [81].

BMP signaling also stimulates MAPK pathways such as, ERK, JNK, p38 [82]. BMP4induced HUVEC sprouting is dependent on ERK [83]. In addition, small molecule inhibitors demonstrated that Bmp2-mediated angiogenesis in zebrafish requires both Smad and Erk activation. 
Furthermore, the Wnt pathway appears to interact with BMP signaling. Active Wnt signaling inhibits GSK3 which allows the accumulation of $\beta$-catenin and downstream gene activation. MAPK and GSK3 phosphorylate the SMAD1 linker region leading to the polyubiquitinylation and degradation of SMAD1 [84]. BMP2 signaling through BMPRII inhibited GSK3- $\beta$, which lead to increased PAEC survival and proliferation. In addition, BMP2 signaling recruited Disheveled (a noncononical Wnt receptor) which promoted RhoA-Rac1 signaling and PAEC motility [31].

BMP signaling also cooperates with VEGF-A signaling (Fig. 2). The over-expression of BMP2, BMP4, BMP6, and BMP7 increased VEGF-A transcription in various cell types [85-87]. VEGF-A neutralizing antibodies inhibited the BMP mediated angiogenic responses in preosteoblast-like cells and in fetal metatarsal assay [85]. However, bmp $2 b$ overexpression in zebrafish induced a robust angiogenic response that is not affected by morpholino inhibition of Vegf-A signaling [47]. Furthermore, the interactions between BMP and VEGF signaling appear to go beyond transcriptional regulation. Dorsomorphin is a small molecule inhibitor that was first reported to be a selective inhibitor of BMP signaling by inhibiting BMP type I receptors and was later shown to also be a potent inhibitor of VEGF signaling by inhibiting the VEGFR2 function [88]. The ability of dorsomorphin to interact and inhibit both type I BMP receptors and VEGF receptors suggests that they might share structural similarities.

\section{Arterial and venous differences in BMP signaling}

Both human vascular diseases associated with BMP signaling, HHT and PAH, affect a distinct subset of endothelial cells. PAH selectively affects the arteries connecting the lungs to the heart. The HHT pathology causes aberrant vascular growths that fail to form proper arterial and venous connections (AVMs) in the skin, digestive tract, lungs, liver and brain. ALK1 linked to both of these vascular disorders [6, 14]. Interestingly, ALK1 is selectively expressed in arterial endothelial cells during murine development and is highly expressed in the lung endothelium of adults [89]

During mammalian eye development the the pupillary membrane regresses and capillaries in this tissue undergo apoptosis (programmed capillary regression) [29]. BMP4 induces endothelial cell apoptosis during programmed capillary regression in rats [90]. While capillary and venous endothelial cells were responsive to BMP4-induced apoptosis, arterial endothelial cells were resistant to BMP4-induced apoptosis. This differential responsiveness to BMP4-mediated apoptosis was shown to be caused by the increased arterial expression of inhibitory SMADs (SMAD6 and SMAD7) [90]. Arterial endothelial cells experience higher levels of shear stress than venous endothelial cells. Fluid mechanical stimulation of cultured endothelial cells induces I-SMAD expression [91], suggesting that shear stress may account some BMP-responsive differences between arterial and venous endothelial cells.

BMP signaling also differentially regulated arterial and venous angiogenesis during zebrafish development. The vascular network of early zebrafish embryos contains a dorsal aorta and an axial vein which extend angiogenic sprouts [92, 93]. This simple vascular network is useful system for studying the arterial and venous differences during vertebrate angiogenesis. Conditional over-expression of noggin 3 and morpholino inhibition of bmpr $2 a$ or $b m p r 2 b$ selectively inhibited venous angiogenesis, while the overexpression of $b m p 2 b$ induced ectopic sprouts from the axial vein but not the axial artery (Fig. 3) [47]. Analogs of dorsomorphin, DMH1 and DMH4, were created which selectively inhibited ALK2, ALK3 or VEGFR2 function, respectively [88]. In accordance, DMH1 (a BMP inhibitor) selectively inhibited venous angiogenesis while DMH4 (a VEGF inhibitor) selectively inhibited arterial angiogenesis in zebrafish [47]. Most interestingly, BMP signaling can promote angiogenesis 
independent of VEGF-A signaling in zebrafish, and elicit distinct angiogenic responses. Collectively, these findings support a model in which VEGF-A and BMP signaling promotes angiogenesis from venous and arterial endothelial cells respectively (Fig. 4) [47]. The factor(s) which make(s) the axial vein responsive and the dorsal aorta refractory to BMP stimulus during early zebrafish development remain to be identified. Discovering these factors will help elucidate the function and relevance of BMP signaling during mammalian angiogenesis.

\section{Concluding Remarks}

As discussed above, both pro-angiogenic and anti-angiogenic functions of BMP signaling have been reported. Considering numerous pathway components, dynamic expression pattern, as well as potential redundancies of BMP signaling, it is not surprising that BMP signaling can elicit diverse responses from endothelial cells. Therefore, it is essential to identify factors confers the context dependent pro- and/or anti-angiogneic effects of BMP signaling and delineate cellular and molecular mechanisms that mediate BMP signaling within endothelial cells to develop a consensus model for the role of BMP signaling in endothelial cells.

\section{Highlights}

Function of Bone Morphogenetic Protein (BMP) signaling is essential in diverse biological processes including angiogenesis. However, how BMP signaling modulates angiogenesis are not fully understood. Here we review recent advances in the field to provide a comprehensive picture of how BMP signaling regulates angiogenesis.

\section{References}

1. Chung WS, Shin CH, Stainier DY. Bmp2 signaling regulates the hepatic versus pancreatic fate decision. Dev Cell. 2008; 15:738-748. [PubMed: 19000838]

2. Kowanetz M, Ferrara N. Vascular endothelial growth factor signaling pathways: therapeutic perspective. Clin Cancer Res. 2006; 12:5018-5022. [PubMed: 16951216]

3. Shibuya M, Claesson-Welsh L. Signal transduction by VEGF receptors in regulation of angiogenesis and lymphangiogenesis. Exp Cell Res. 2006; 312:549-560. [PubMed: 16336962]

4. Shi Y, Massague J. Mechanisms of TGF-beta signaling from cell membrane to the nucleus. Cell. 2003; 113:685-700. [PubMed: 12809600]

5. Derynck R, Zhang YE. Smad-dependent and Smad-independent pathways in TGF-beta family signalling. Nature. 2003; 425:577-584. [PubMed: 14534577]

6. Johnson DW, Berg JN, Baldwin MA, Gallione CJ, Marondel I, Yoon SJ, Stenzel TT, Speer M, Pericak-Vance MA, Diamond A, Guttmacher AE, Jackson CE, Attisano L, Kucherlapati R, Porteous ME, Marchuk DA. Mutations in the activin receptor-like kinase 1 gene in hereditary haemorrhagic telangiectasia type 2. Nat Genet. 1996; 13:189-195. [PubMed: 8640225]

7. McAllister KA, Grogg KM, Johnson DW, Gallione CJ, Baldwin MA, Jackson CE, Helmbold EA, Markel DS, McKinnon WC, Murrell J, et al. Endoglin, a TGF-beta binding protein of endothelial cells, is the gene for hereditary haemorrhagic telangiectasia type 1. Nat Genet. 1994; 8:345-351. [PubMed: 7894484]

8. Shovlin CL, Guttmacher AE, Buscarini E, Faughnan ME, Hyland RH, Westermann CJ, Kjeldsen $\mathrm{AD}$, Plauchu H. Diagnostic criteria for hereditary hemorrhagic telangiectasia (Rendu-Osler-Weber syndrome). Am J Med Genet. 2000; 91:66-67. [PubMed: 10751092]

9. Li DY, Sorensen LK, Brooke BS, Urness LD, Davis EC, Taylor DG, Boak BB, Wendel DP. Defective angiogenesis in mice lacking endoglin. Science. 1999; 284:1534-1537. [PubMed: 10348742] 
10. Oh SP, Seki T, Goss KA, Imamura T, Yi Y, Donahoe PK, Li L, Miyazono K, ten Dijke P, Kim S, Li E. Activin receptor-like kinase 1 modulates transforming growth factor-beta 1 signaling in the regulation of angiogenesis. Proc Natl Acad Sci U S A. 2000; 97:2626-2631. [PubMed: 10716993]

11. Park SO, Lee YJ, Seki T, Hong KH, Fliess N, Jiang Z, Park A, Wu X, Kaartinen V, Roman BL, Oh SP. ALK5- and TGFBR2-independent role of ALK1 in the pathogenesis of hereditary hemorrhagic telangiectasia type 2. Blood. 2008; 111:633-642. [PubMed: 17911384]

12. Torsney E, Charlton R, Diamond AG, Burn J, Soames JV, Arthur HM. Mouse model for hereditary hemorrhagic telangiectasia has a generalized vascular abnormality. Circulation. 2003; 107:16531657. [PubMed: 12668501]

13. Urness LD, Sorensen LK, Li DY. Arteriovenous malformations in mice lacking activin receptorlike kinase-1. Nat Genet. 2000; 26:328-331. [PubMed: 11062473]

14. Harrison RE, Berger R, Haworth SG, Tulloh R, Mache CJ, Morrell NW, Aldred MA, Trembath RC. Transforming growth factor-beta receptor mutations and pulmonary arterial hypertension in childhood. Circulation. 2005; 111:435-441. [PubMed: 15687131]

15. Lane KB, Machado RD, Pauciulo MW, Thomson JR, Phillips JA 3rd, Loyd JE, Nichols WC, Trembath RC. Heterozygous germline mutations in BMPR2, encoding a TGF-beta receptor, cause familial primary pulmonary hypertension. Nat Genet. 2000; 26:81-84. [PubMed: 10973254]

16. Shintani M, Yagi H, Nakayama T, Saji T, Matsuoka R. A new nonsense mutation of SMAD8 associated with pulmonary arterial hypertension. J Med Genet. 2009; 46:331-337. [PubMed: 19211612]

17. Beppu H, Ichinose F, Kawai N, Jones RC, Yu PB, Zapol WM, Miyazono K, Li E, Bloch KD. BMPR-II heterozygous mice have mild pulmonary hypertension and an impaired pulmonary vascular remodeling response to prolonged hypoxia. Am J Physiol Lung Cell Mol Physiol. 2004; 287:L1241-L1247. [PubMed: 15286002]

18. Liu D, Wang J, Kinzel B, Mueller M, Mao X, Valdez R, Liu Y, Li E. Dosage-dependent requirement of BMP type II receptor for maintenance of vascular integrity. Blood. 2007; 110:1502-1510. [PubMed: 17496203]

19. Kawabata M, Imamura T, Miyazono K. Signal transduction by bone morphogenetic proteins. Cytokine \& Growth Factor Reviews. 1998; vol. 9:49-61. [PubMed: 9720756]

20. Little SC, Mullins MC. Bone morphogenetic protein heterodimers assemble heteromeric type I receptor complexes to pattern the dorsoventral axis. Nat Cell Biol. 2009; 11:637-643. [PubMed: 19377468]

21. Macías-Silva M, Hoodless PA, Tang SJ, Buchwald M, Wrana JL. Specific Activation of Smad1 Signaling Pathways by the BMP7 Type I Receptor, ALK2. Journal of Biological Chemistry. 1998; 273:25628-25636. [PubMed: 9748228]

22. ten Dijke P, Yamashita H, Sampath TK, Reddi AH, Estevez M, Riddle DL, Ichijo H, Heldin CH, Miyazono K. Identification of type I receptors for osteogenic protein-1 and bone morphogenetic protein-4. J Biol Chem. 1994; 269:16985-16988. [PubMed: 8006002]

23. Ebisawa T, Tada K, Kitajima I, Tojo K, Sampath TK, Kawabata M, Miyazono K, Imamura T. Characterization of bone morphogenetic protein-6 signaling pathways in osteoblast differentiation. J Cell Sci. 1999; 112(Pt 20):3519-3527. [PubMed: 10504300]

24. Yamashita H, ten Dijke P, Huylebroeck D, Sampath TK, Andries M, Smith JC, Heldin CH, Miyazono K. Osteogenic protein-1 binds to activin type II receptors and induces certain activinlike effects. J Cell Biol. 1995; 130:217-226. [PubMed: 7790373]

25. Erlacher L, McCartney J, Piek E, ten Dijke P, Yanagishita M, Oppermann H, Luyten FP. Cartilagederived morphogenetic proteins and osteogenic protein-1 differentially regulate osteogenesis. $\mathrm{J}$ Bone Miner Res. 1998; 13:383-392. [PubMed: 9525338]

26. Nishitoh H, Ichijo H, Kimura M, Matsumoto T, Makishima F, Yamaguchi A, Yamashita H, Enomoto S, Miyazono K. Identification of type I and type II serine/threonine kinase receptors for growth/differentiation factor-5. J Biol Chem. 1996; 271:21345-21352. [PubMed: 8702914]

27. Brown MA, Zhao Q, Baker KA, Naik C, Chen C, Pukac L, Singh M, Tsareva T, Parice Y, Mahoney A, Roschke V, Sanyal I, Choe S. Crystal structure of BMP-9 and functional interactions with pro-region and receptors. J Biol Chem. 2005; 280:25111-25118. [PubMed: 15851468] 
28. David L, Mallet C, Vailhe B, Lamouille S, Feige JJ, Bailly S. Activin receptor-like kinase 1 inhibits human microvascular endothelial cell migration: potential roles for JNK and ERK. J Cell Physiol. 2007; 213:484-489. [PubMed: 17620321]

29. Langenfeld EM, Langenfeld J. Bone morphogenetic protein- 2 stimulates angiogenesis in developing tumors. Mol Cancer Res. 2004; 2:141-149. [PubMed: 15037653]

30. Raida M, Clement JH, Leek RD, Ameri K, Bicknell R, Niederwieser D, Harris AL. Bone morphogenetic protein 2 (BMP-2) and induction of tumor angiogenesis. J Cancer Res Clin Oncol. 2005; 131:741-750. [PubMed: 16136355]

31. de Jesus Perez VA, Alastalo TP, Wu JC, Axelrod JD, Cooke JP, Amieva M, Rabinovitch M. Bone morphogenetic protein 2 induces pulmonary angiogenesis via Wnt-beta-catenin and WntRhoARac1 pathways. J Cell Biol. 2009; 184:83-99. [PubMed: 19139264]

32. Rothhammer T, Bataille F, Spruss T, Eissner G, Bosserhoff AK. Functional implication of BMP4 expression on angiogenesis in malignant melanoma. Oncogene. 2007; 26:4158-4170. [PubMed: 17173062]

33. Reese DE, Hall CE, Mikawa T. Negative Regulation of Midline Vascular Development by the Notochord. Developmental Cell. 2004; 6:699-708. [PubMed: 15130494]

34. Nimmagadda S, Geetha Loganathan P, Huang R, Scaal M, Schmidt C, Christ B. BMP4 and noggin control embryonic blood vessel formation by antagonistic regulation of VEGFR-2 (Quek1) expression. Developmental Biology. 2005; 280:100-110. [PubMed: 15766751]

35. Stabile H, Mitola S, Moroni E, Belleri M, Nicoli S, Coltrini D, Peri F, Pessi A, Orsatti L, Talamo F, Castronovo V, Waltregny D, Cotelli F, Ribatti D, Presta M. Bone morphogenic protein antagonist Drm/gremlin is a novel proangiogenic factor. Blood. 2007; 109:1834-1840. [PubMed: 17077323]

36. Suzuki Y, Montagne K, Nishihara A, Watabe T, Miyazono K. BMPs promote proliferation and migration of endothelial cells via stimulation of VEGF-A/VEGFR2 and angiopoietin-1/Tie2 signalling. J Biochem. 2008; 143:199-206. [PubMed: 18006519]

37. Ren R, Charles PC, Zhang C, Wu Y, Wang H, Patterson C. Gene expression profiles identify a role for cyclooxygenase 2- dependent prostanoid generation in BMP6-induced angiogenic responses. Blood. 2007; 109:2847-2853. [PubMed: 17119124]

38. Valdimarsdottir G, Goumans M-J, Rosendahl A, Brugman M, Itoh S, Lebrin F, Sideras P, ten Dijke P. Stimulation of Id1 Expression by Bone Morphogenetic Protein Is Sufficient and Necessary for Bone Morphogenetic Protein-Induced Activation of Endothelial Cells. Circulation. 2002; 106:2263-2270. [PubMed: 12390958]

39. Ramoshebi LN, Ripamonti U. Osteogenic protein-1, a bone morphogenetic protein, induces angiogenesis in the chick chorioallantoic membrane and synergizes with basic fibroblast growth factor and transforming growth factor-beta1. Anat Rec. 2000; 259:97-107. [PubMed: 10760748]

40. Yamashita H, Shimizu A, Kato M, Nishitoh H, Ichijo H, Hanyu A, Morita I, Kimura M, Makishima F, Miyazono K. Growth/differentiation factor-5 induces angiogenesis in vivo. Exp Cell Res. 1997; 235:218-226. [PubMed: 9281371]

41. David L, Mallet C, Keramidas M, Lamande N, Gasc JM, Dupuis-Girod S, Plauchu H, Feige JJ, Bailly S. Bone morphogenetic protein-9 is a circulating vascular quiescence factor. Circ Res. 2008; 102:914-922. [PubMed: 18309101]

42. Scharpfenecker M, van Dinther M, Liu Z, van Bezooijen RL, Zhao Q, Pukac L, Lowik CWGM, ten Dijke P. BMP-9 signals via ALK1 and inhibits bFGF-induced endothelial cell proliferation and VEGF-stimulated angiogenesis. J Cell Sci. 2007; 120:964-972. [PubMed: 17311849]

43. Roman BL, Pham VN, Lawson ND, Kulik M, Childs S, Lekven AC, Garrity DM, Moon RT, Fishman MC, Lechleider RJ, Weinstein BM. Disruption of acvrl1 increases endothelial cell number in zebrafish cranial vessels. Development. 2002; 129:3009-3019. [PubMed: 12050147]

44. Mallet C, Vittet D, Feige JJ, Bailly S. TGFbeta1 induces vasculogenesis and inhibits angiogenic sprouting in an embryonic stem cell differentiation model: respective contribution of ALK1 and ALK5. Stem Cells. 2006; 24:2420-2427. [PubMed: 17071858]

45. Lamouille S, Mallet C, Feige JJ, Bailly S. Activin receptor-like kinase 1 is implicated in the maturation phase of angiogenesis. Blood. 2002; 100:4495-4501. [PubMed: 12453878] 
46. Goumans M-J, Valdimarsdottir G, Itoh S, Rosendahl A, Sideras P, ten Dijke P. Balancing the activation state of the endothelium via two distinct TGF-[beta] type I receptors. EMBO J. 2002; 21:1743-1753. [PubMed: 11927558]

47. Wiley DM, Kim JD, Hao J, Hong CC, Bautch VL, Jin SW. Distinct signalling pathways regulate sprouting angiogenesis from the dorsal aorta and the axial vein. Nat. Cell Biol. 2011; 13:686-692. [PubMed: 21572418]

48. Hartung A, Bitton-Worms K, Rechtman MM, Wenzel V, Boergermann JH, Hassel S, Henis YI, Knaus P. Different routes of bone morphogenic protein (BMP) receptor endocytosis influence BMP signaling. Mol Cell Biol. 2006; 26:7791-7805. [PubMed: 16923969]

49. Nohe A, Hassel S, Ehrlich M, Neubauer F, Sebald W, Henis YI, Knaus P. The mode of bone morphogenetic protein (BMP) receptor oligomerization determines different BMP-2 signaling pathways. J Biol Chem. 2002; 277:5330-5338. [PubMed: 11714695]

50. Nohe A, Keating E, Underhill TM, Knaus P, Petersen NO. Dynamics and interaction of caveolin-1 isoforms with BMPreceptors. J Cell Sci. 2005; 118:643-650. [PubMed: 15657086]

51. Babitt JL, Zhang Y, Samad TA, Xia Y, Tang J, Campagna JA, Schneyer AL, Woolf CJ, Lin HY. Repulsive guidance molecule (RGMa), a DRAGON homologue, is a bone morphogenetic protein co-receptor. J Biol Chem. 2005; 280:29820-29827. [PubMed: 15975920]

52. Hassel S, Yakymovych M, Hellman U, Ronnstrand L, Knaus P, Souchelnytskyi S. Interaction and functional cooperation between the serine/threonine kinase bone morphogenetic protein type II receptor with the tyrosine kinase stem cell factor receptor. J Cell Physiol. 2006; 206:457-467. [PubMed: 16155937]

53. Kirkbride KC, Townsend TA, Bruinsma MW, Barnett JV, Blobe GC. Bone morphogenetic proteins signal through the transforming growth factor-beta type III receptor. J Biol Chem. 2008; 283:7628-7637. [PubMed: 18184661]

54. Samad TA, Rebbapragada A, Bell E, Zhang Y, Sidis Y, Jeong SJ, Campagna JA, Perusini S, Fabrizio DA, Schneyer AL, Lin HY, Brivanlou AH, Attisano L, Woolf CJ. DRAGON, a bone morphogenetic protein co-receptor. J Biol Chem. 2005; 280:14122-14129. [PubMed: 15671031]

55. Sammar M, Stricker S, Schwabe GC, Sieber C, Hartung A, Hanke M, Oishi I, Pohl J, Minami Y, Sebald W, Mundlos S, Knaus P. Modulation of GDF5/BRI-b signalling through interaction with the tyrosine kinase receptor Ror2. Genes Cells. 2004; 9:1227-1238. [PubMed: 15569154]

56. Onichtchouk D, Chen YG, Dosch R, Gawantka V, Delius H, Massague J, Niehrs C. Silencing of TGF-beta signalling by the pseudoreceptor BAMBI. Nature. 1999; 401:480-485. [PubMed: 10519551]

57. Foletta VC, Lim MA, Soosairajah J, Kelly AP, Stanley EG, Shannon M, He W, Das S, Massague J, Bernard O. Direct signaling by the BMP type II receptor via the cytoskeletal regulator LIMK1. J Cell Biol. 2003; 162:1089-1098. [PubMed: 12963706]

58. Machado RD, Rudarakanchana N, Atkinson C, Flanagan JA, Harrison R, Morrell NW, Trembath RC. Functional interaction between BMPR-II and Tctex-1, a light chain of Dynein, is isoformspecific and disrupted by mutations underlying primary pulmonary hypertension. Hum Mol Genet. 2003; 12:3277-3286. [PubMed: 14583445]

59. Wong WK, Knowles JA, Morse JH. Bone morphogenetic protein receptor type II C-terminus interacts with c-Src: implication for a role in pulmonary arterial hypertension. Am J Respir Cell Mol Biol. 2005; 33:438-446. [PubMed: 16002577]

60. Aramaki T, Sasai N, Yakura R, Sasai Y. Jiraiya attenuates BMP signaling by interfering with type II BMP receptors in neuroectodermal patterning. Dev Cell. 2010; 19:547-561. [PubMed: 20951346]

61. Avsian-Kretchmer O, Hsueh AJ. Comparative genomic analysis of the eight-membered ring cystine knot-containing bone morphogenetic protein antagonists. Mol Endocrinol. 2004; 18:1-12. [PubMed: 14525956]

62. Pearce JJ, Penny G, Rossant J. A mouse cerberus/Dan-related gene family. Dev Biol. 1999; 209:98-110. [PubMed: 10208746]

63. Piccolo S, Agius E, Leyns L, Bhattacharyya S, Grunz H, Bouwmeester T, De Robertis EM. The head inducer Cerberus is a multifunctional antagonist of Nodal, BMP and Wnt signals. Nature. 1999; 397:707-710. [PubMed: 10067895] 
64. Merino R, Rodriguez-Leon J, Macias D, Ganan Y, Economides AN, Hurle JM. The BMP antagonist Gremlin regulates outgrowth, chondrogenesis and programmed cell death in the developing limb. Development. 1999; 126:5515-5522. [PubMed: 10556075]

65. Winkler DG, Sutherland MK, Geoghegan JC, Yu C, Hayes T, Skonier JE, Shpektor D, Jonas M, Kovacevich BR, Staehling-Hampton K, Appleby M, Brunkow ME, Latham JA. Osteocyte control of bone formation via sclerostin, a novel BMP antagonist. Embo J. 2003; 22:6267-6276. [PubMed: 14633986]

66. Oelgeschlager M, Larrain J, Geissert D, De Robertis EM. The evolutionarily conserved BMPbinding protein Twisted gastrulation promotes BMP signalling. Nature. 2000; 405:757-763. [PubMed: 10866189]

67. Piccolo S, Agius E, Lu B, Goodman S, Dale L, De Robertis EM. Cleavage of Chordin by Xolloid metalloprotease suggests a role for proteolytic processing in the regulation of Spemann organizer activity. Cell. 1997; 91:407-416. [PubMed: 9363949]

68. Zimmerman LB, De Jesus-Escobar JM, Harland RM. The Spemann organizer signal noggin binds and inactivates bone morphogenetic protein 4. Cell. 1996; 86:599-606. [PubMed: 8752214]

69. Yanagita M. BMP antagonists: their roles in development and involvement in pathophysiology. Cytokine Growth Factor Rev. 2005; 16:309-317. [PubMed: 15951218]

70. Yanagita M, Oka M, Watabe T, Iguchi H, Niida A, Takahashi S, Akiyama T, Miyazono K, Yanagisawa M, Sakurai T. USAG-1: a bone morphogenetic protein antagonist abundantly expressed in the kidney. Biochem Biophys Res Commun. 2004; 316:490-500. [PubMed: 15020244]

71. Yanagita M, Okuda T, Endo S, Tanaka M, Takahashi K, Sugiyama F, Kunita S, Takahashi S, Fukatsu A, Yanagisawa M, Kita T, Sakurai T. Uterine sensitization-associated gene-1 (USAG-1), a novel BMP antagonist expressed in the kidney, accelerates tubular injury. J Clin Invest. 2006; 116:70-79. [PubMed: 16341262]

72. Bressan M, Davis P, Timmer J, Herzlinger D, Mikawa T. Notochord-derived BMP antagonists inhibit endothelial cell generation and network formation. Dev Biol. 2009; 326:101-111. [PubMed: 19041859]

73. Reese DE, Hall CE, Mikawa T. Negative regulation of midline vascular development by the notochord. Dev Cell. 2004; 6:699-708. [PubMed: 15130494]

74. Garriock RJ, Czeisler C, Ishii Y, Navetta AM, Mikawa T. An anteroposterior wave of vascular inhibitor downregulation signals aortae fusion along the embryonic midline axis. Development. 2010; 137:3697-3706. [PubMed: 20940228]

75. Moser M, Binder O, Wu Y, Aitsebaomo J, Ren R, Bode C, Bautch VL, Conlon FL, Patterson C. BMPER, a novel endothelial cell precursor-derived protein, antagonizes bone morphogenetic protein signaling and endothelial cell differentiation. Mol Cell Biol. 2003; 23:5664-5679. [PubMed: 12897139]

76. Conley CA, Silburn R, Singer MA, Ralston A, Rohwer-Nutter D, Olson DJ, Gelbart W, Blair SS. Crossveinless 2 contains cysteine-rich domains and is required for high levels of BMP-like activity during the formation of the cross veins in Drosophila. Development. 2000; 127:3947-3959. [PubMed: 10952893]

77. Serpe M, Umulis D, Ralston A, Chen J, Olson DJ, Avanesov A, Othmer H, O'Connor MB, Blair SS. The BMP-binding protein Crossveinless 2 is a short-range, concentration-dependent, biphasic modulator of BMP signaling in Drosophila. Dev Cell. 2008; 14:940-953. [PubMed: 18539121]

78. Kelley R, Ren R, Pi X, Wu Y, Moreno I, Willis M, Moser M, Ross M, Podkowa M, Attisano L, Patterson C. A concentration-dependent endocytic trap and sink mechanism converts Bmper from an activator to an inhibitor of Bmp signaling. J Cell Biol. 2009; 184:597-609. [PubMed: 19221194]

79. Zakin L, Metzinger CA, Chang EY, Coffinier C, De Robertis EM. Development of the vertebral morphogenetic field in the mouse: interactions between Crossveinless-2 and Twisted Gastrulation. Dev Biol. 2008; 323:6-18. [PubMed: 18789316]

80. Moreno-Miralles I, Schisler JC, Patterson C. New insights into bone morphogenetic protein signaling: focus on angiogenesis. Curr Opin Hematol. 2009; 16:195-201. [PubMed: 19346940] 
81. Pi X, Ren R, Kelley R, Zhang C, Moser M, Bohil AB, Divito M, Cheney RE, Patterson C. Sequential roles for myosin- $\mathrm{X}$ in BMP6-dependent filopodial extension, migration, and activation of BMP receptors. J Cell Biol. 2007; 179:1569-1582. [PubMed: 18158328]

82. Miyazono K, Maeda S, Imamura T. BMP receptor signaling: transcriptional targets, regulation of signals, and signaling crosstalk. Cytokine Growth Factor Rev. 2005; 16:251-263. [PubMed: 15871923]

83. Zhou Q, Heinke J, Vargas A, Winnik S, Krauss T, Bode C, Patterson C, Moser M. ERK signaling is a central regulator for BMP-4 dependent capillary sprouting. Cardiovasc Res. 2007; 76:390 399. [PubMed: 17850776]

84. Fuentealba LC, Eivers E, Ikeda A, Hurtado C, Kuroda H, Pera EM, De Robertis EM. Integrating Patterning Signals: Wnt/GSK3 Regulates the Duration of the BMP/Smad1 Signal. Cell. 2007; 131:980-993. [PubMed: 18045539]

85. Deckers MM, van Bezooijen RL, van der Horst G, Hoogendam J, van Der Bent C, Papapoulos SE, Lowik CW. Bone morphogenetic proteins stimulate angiogenesis through osteoblast-derived vascular endothelial growth factor A. Endocrinology. 2002; 143:1545-1553. [PubMed: 11897714]

86. Kozawa O, Matsuno H, Uematsu T. Involvement of p70 S6 kinase in bone morphogenetic protein signaling: vascular endothelial growth factor synthesis by bone morphogenetic protein- 4 in osteoblasts. J Cell Biochem. 2001; 81:430-436. [PubMed: 11255225]

87. Yeh LC, Lee JC. Osteogenic protein-1 increases gene expression of vascular endothelial growth factor in primary cultures of fetal rat calvaria cells. Mol Cell Endocrinol. 1999; 153:113-124. [PubMed: 10459859]

88. Hao J, Ho JN, Lewis JA, Karim KA, Daniels RN, Gentry PR, Hopkins CR, Lindsley CW, Hong CC. In vivo structure-activity relationship study of dorsomorphin analogues identifies selective VEGF and BMP inhibitors. ACS Chem Biol. 2009; 5:245-253. [PubMed: 20020776]

89. Seki T, Yun J, Oh SP. Arterial endothelium-specific activin receptor-like kinase 1 expression suggests its role in arterialization and vascular remodeling. Circ Res. 2003; 93:682-689. [PubMed: 12970115]

90. Kiyono M, Shibuya M. Bone morphogenetic protein 4 mediates apoptosis of capillary endothelial cells during rat pupillary membrane regression. Mol Cell Biol. 2003; 23:4627-4636. [PubMed: 12808102]

91. Topper JN, Cai J, Qiu Y, Anderson KR, Xu YY, Deeds JD, Feeley R, Gimeno CJ, Woolf EA, Tayber O, Mays GG, Sampson BA, Schoen FJ, Gimbrone MA Jr, Falb D. Vascular MADs: two novel MAD-related genes selectively inducible by flow in human vascular endothelium. Proc Natl Acad Sci U S A. 1997; 94:9314-9319. [PubMed: 9256479]

92. Isogai S, Horiguchi M, Weinstein BM. The vascular anatomy of the developing zebrafish: an atlas of embryonic and early larval development. Dev Biol. 2001; 230:278-301. [PubMed: 11161578]

93. Isogai S, Lawson ND, Torrealday S, Horiguchi M, Weinstein BM. Angiogenic network formation in the developing vertebrate trunk. Development. 2003; 130:5281-5290. [PubMed: 12954720] 


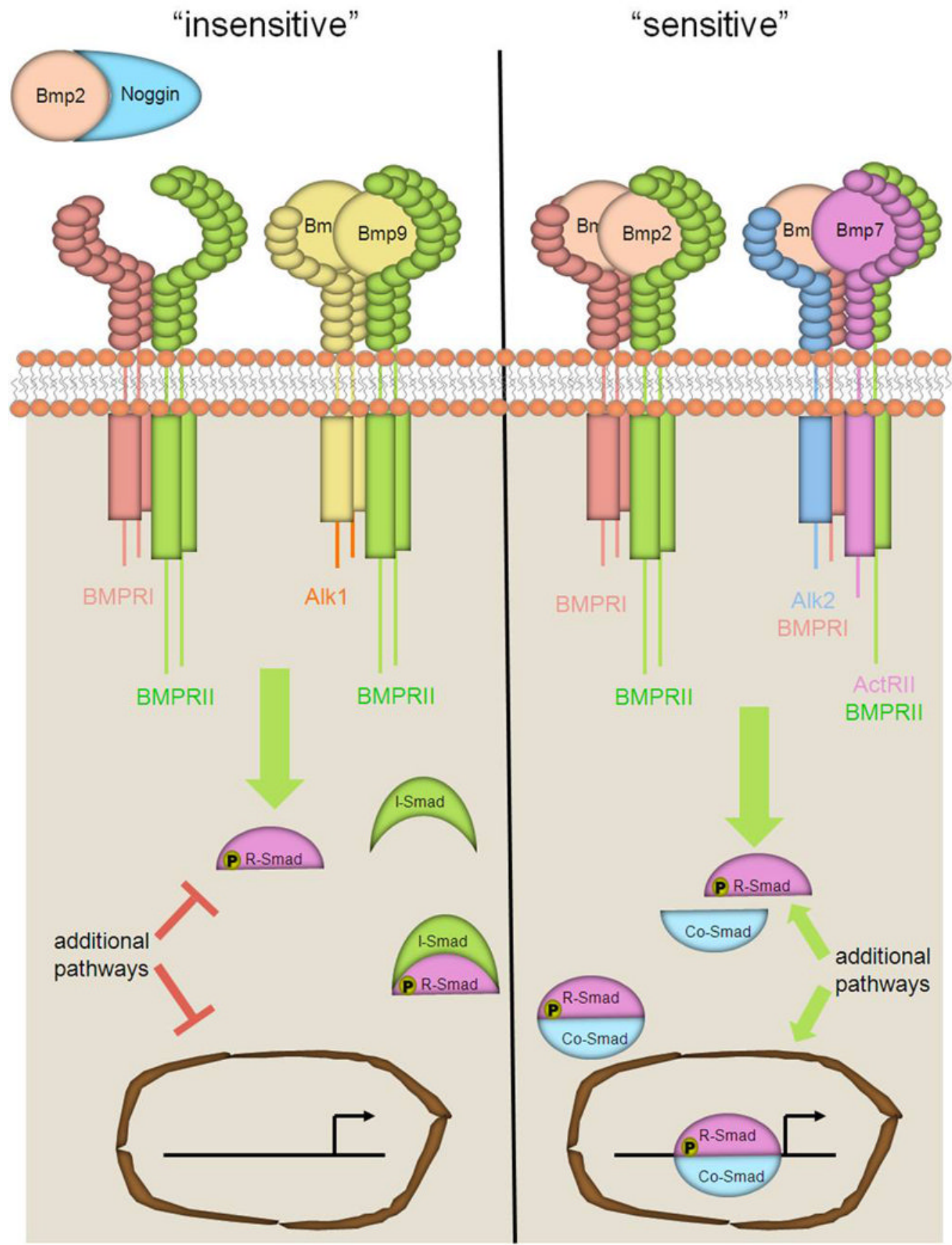

Fig. 1. Methods of regulating BMP responsiveness

Extracellular antagonists bind to BMP ligands and prevent the ligands from interacting with receptors. BMP9 BMP10 bind to non-angiogenic heteromeric receptor complexes consisting of BMPRII and ALK1, which may limit the availability of angiogenic ligand-receptor complexes. In contrast, when angiogenic ligand-receptor complexes are formed, and inhibitory BMP ligands are absent, co-SMAD is translocated into the nucleus and promotes the transcription of BMP target genes within endothelial cells. Alternative signaling pathways may also have important roles in regulating the intracelluar responses to BMP stimulus. 


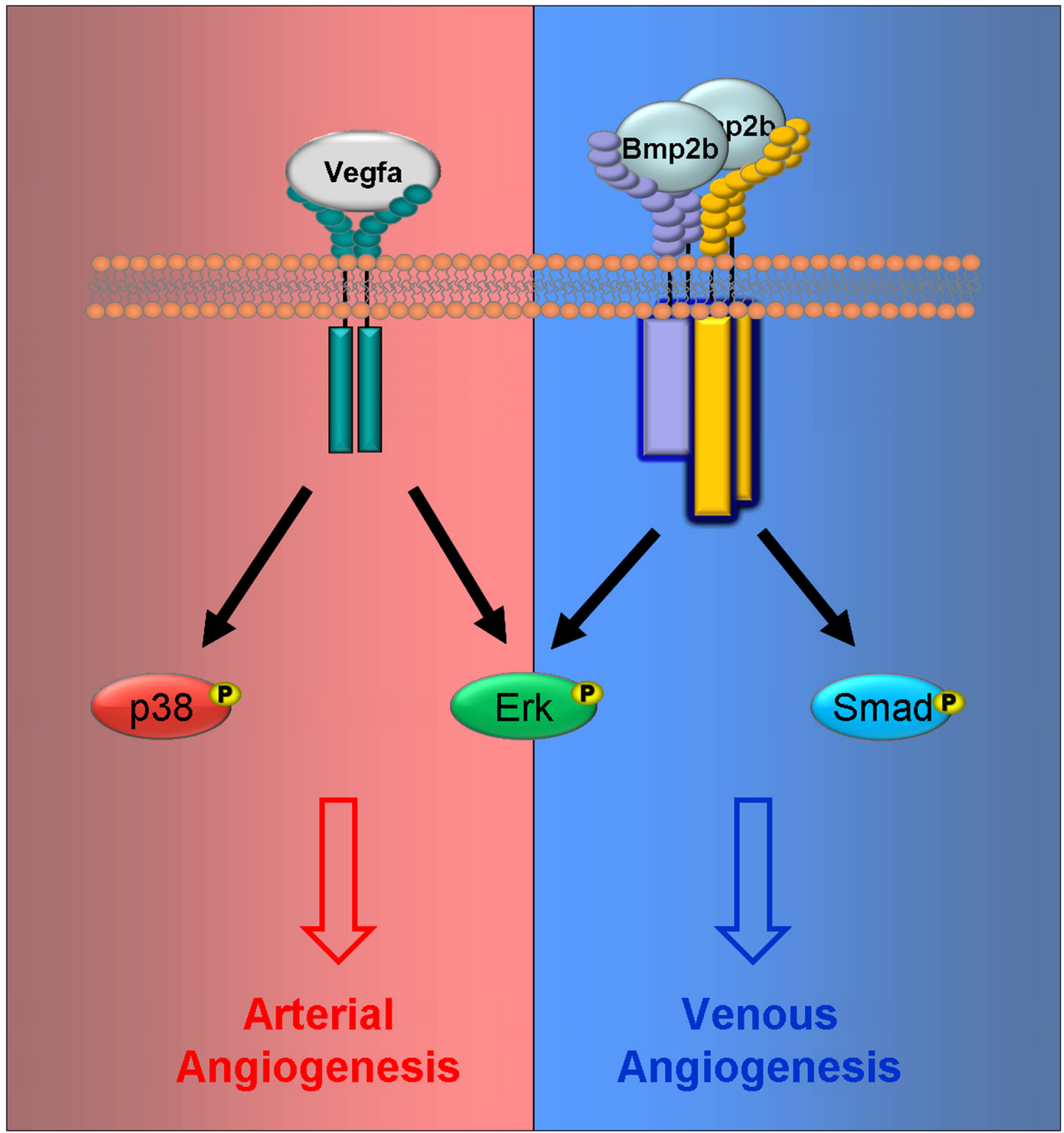

Figure 2.

VEGFA and BMP pathways have distinct as well as overlapping intracellular targets. The VEGFA pathway is known to phosphorylate and activate, among other factors, MAPK signaling cascades, which includes both p38 and ERK. Canonical BMP signaling activates Smads however BMP stimulation has been shown to effectively activate MAPK signaling cascades as well. During angiogenesis, BMP requires activation of ERK and not p38 [47]. 


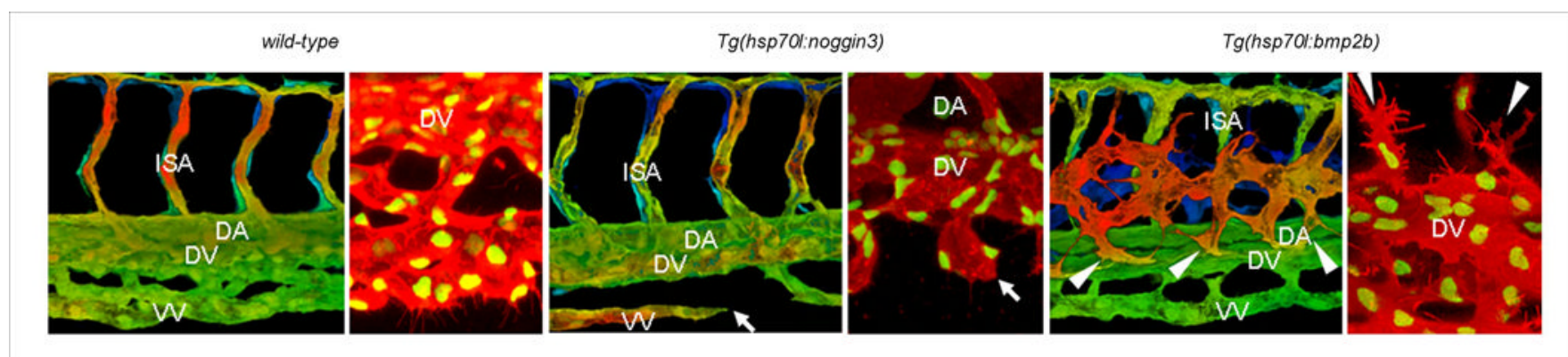

Figure 3.

Bmp signaling is necessary and sufficient for sprouting from the axial vein. Blood vessels in wild-type (A, B), $T g$ (hsp70:noggin3) (C, D) and $T g$ (hsp70:bmp2b) (E, F) embryos in the $T g(k d r l: G F P)$ transgenic background (A, C, E). The entire vascular network of $42 \mathrm{hpf}$ embryos was analyzed using epiflourescent images; dashed boxes represent the trunk and tail areas analyzed below. Z-stacks from the trunk and tail regions were used to make 3-D color projections (A, C, and E), Filopodia formation of Tg(fli1:nGFP); $T g(k d r l: r a s-m C h e r r y)$ embryos starting at $32 \mathrm{hpf}(\mathrm{B}, \mathrm{D}$, and F). Arrows in panel $\mathrm{c}$ and $\mathrm{d}$ show sprouts from the axial vein that fail to make connections in $T g(h s p 70: n o g g i n 3)$ embryos. Arrowheads in panel e and $\mathrm{f}$ point to ectopic sprouts that branch from the axial vein in $T g$ (hsp $70: b m p 2 b$ ) embryos. Abbreviations: DA, dorsal aorta; VV, ventral vein; DV, dorsal vein; NC, notocord; NT, neural tube; ISA, intersegmental artery. 


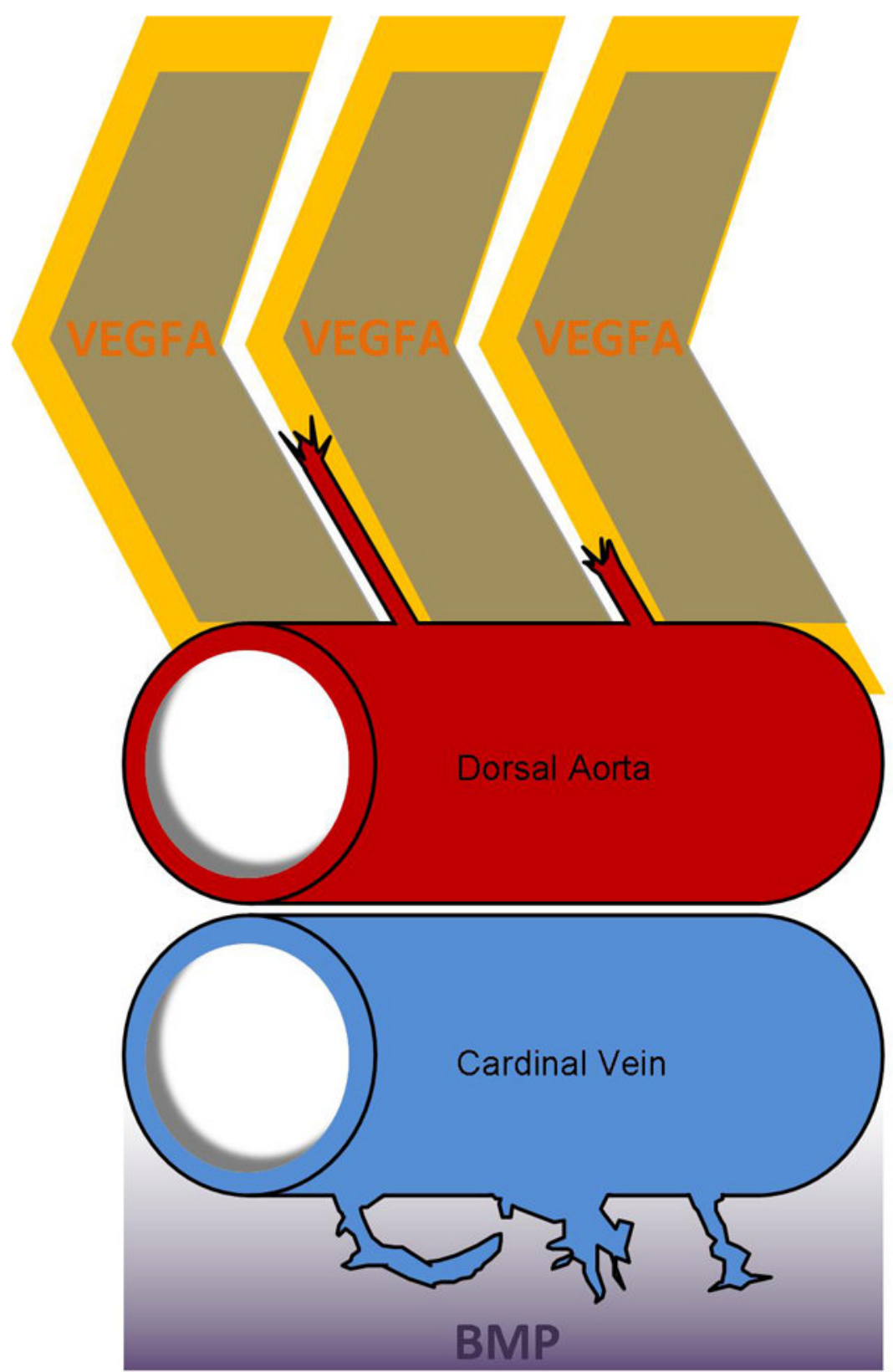

Figure 4.

Distinct angiogenic cues regulate arterial and venous angiogenesis during early zebrafish development. VEGFA regulates sprouting from the Dorsal Aorta, while BMP signaling is the predominate angiogenic cue during venous angiogenesis off the Axial Vein. VEGFA expressed dorsally within somites attracts sprouts from the Dorsal Aorta. Meanwhile, ventral expression of BMP regulates sprouting from the axial vein. 